\title{
Global justice and genomics: Toward global agro-genomics agency
}

\author{
MICHIEL KORTHALS ${ }^{1}$
}

\begin{abstract}
Searching for the specific contribution of the life sciences to global justice in agriculture and food, one is faced with six global problems that haunt the world today. These are: population growth (9.2 billion by 2050); the gap between poor and rich peoples; hunger and obesity; increasing environmental pressures; climate change; and instable power relations and systems. Most of them seem to have a strong connection with the dominant system in agriculture which is high input and capital- and resourceintensive with high energetic output (food), at the cost of other factors important for sustainable development, like food quality, fresh water and liveable temperatures. However, beside this dominant system there is a plurality of other, often local, agricultural systems that don't have these disadvantages or have them in a lesser degree, and they are in particular located in the South. The current prominent perspectives on global justice, like the consequence-oriented one of Peter Singer and the rights- and institutions-oriented one of Thomas Pogge, neglect the importance of plural and local agricultural and food practices for sustainable and fair global development. Partly complementary to these perspectives, Amartya Sen has developed a capabilities approach that emphasises human capacities and the role of democracy. In complementing his approach we develop an agency- and practiceoriented perspective that stresses the importance of networking the agricultural practices that strive to enhance the quantity and quality of food systems. The tasks of the life sciences for agriculture and food would then be to develop technologies that take into account the plural practices of the poor in the production, processing and consumption of food. This whole chain oriented approach requires from life scientists more than just doing research in laboratories; their task is also to connect their laboratory work with farmers' practices and experiments.
\end{abstract}

\section{Introduction}

According to the current UN Special Rapporteur on the Right to Food, Olivier de Schutter, "(o)nly 6 per cent of privately funded agricultural research is focused on developing country agriculture" (p.13, note 18). ${ }^{2}$ Add to this the decline in publicly funded research in agriculture, and together these imply that plant life sciences are not considering sufficiently the needs of poor farmers and the hungry and underfed in general. This fact is against Article 25.1 of the Universal Declaration of Human Rights (UDHR): "Everyone has the right to a standard of living adequate for the health and well-being of himself and of his family, including food, clothing, housing and medical care and necessary social services, and the right to security in the event of unemployment, sickness, disability, widowhood, old age or other lack of livelihood in circumstances beyond his control." 3 It is also against Article 27.1: "Everyone has the right freely to participate in the cultural life of the community, to enjoy the arts and to share in scientific advancement and its benefits." The failure of the life

Genomics, Society and Policy, Vol.6, No.2 (2010) ISSN: 1746-5354

(C) ESRC Genomics Network. 
sciences to meet the requirements of global justice as defined by the UN makes it more urgent to ask: What does global justice require? How far do and should (plant) life sciences contribute to global justice? What directions, what priorities should the life sciences select in performing this task?

In this article, I will try to give some ideas that might help to answer these two questions. First, I will show that anyone who wants to improve global justice will be confronted with at least six big problems that are complex and intertwined. I will show that most of these problems are connected with agriculture and food (production and consumption), and I will therefore outline the current situation of agriculture which is dominated by the 'productionist' system, although alternative agricultural systems can still be identified. The choice between the different systems confronts us with an ethical dilemma. To better conceptualise this dilemma I will give an overview of the different ethical perspectives on global justice, and show that an agent- and practice-oriented perspective has good chances to improve global justice. In the second part of the paper, I will concentrate on the opportunities for and barriers to life sciences research and development in tackling these problems and the dilemma.

\section{Global problems: population growth, poverty, hunger, environmental pressure, climate change, power}

Anyone who is concerned about the state of global justice (as defined by the UDHR) and the possible contributions of the life sciences to reduce global injustice is confronted with several continuing and persistent problems.

The first is ever-increasing population growth; it is estimated that by 2050 the world population will have grown from 6.8 billion at present to 9.2 billion. ${ }^{4}$ Taking into account the other problems (below), this number makes increasing crop yields a necessity.

Second, the gap between poor and rich peoples is all-pervasive and will become more dramatic than ever. In general, with respect to the use of resources, one can speak of the 10/90 gap: "Only 10 per cent of global health research is devoted to conditions that account for 90 per cent of the global disease burden." The report by De Schutter mentioned earlier also illustrates the '10/90 gap' in agriculture, food and health research, showing that the "needs of poor farmers in developing countries have been comparatively neglected". Given that most poor people are farmers (more than two billion), the decline of agricultural research for the developing world is particularly alarming.

Third, as a consequence, food insecurity is increasing, causing hunger, due both to lack of calories and proteins and to lack of essential micronutrient ingredients. Micronutrient malnutrition is a severe problem because more than half of the world's hungry people are hungry not due to lack of calories and proteins but due to lack of essential minerals and vitamins, resulting in severe disease and poor body function.

Genomics, Society and Policy, Vol.6, No.2 (2010) ISSN: 1746-5354

(C) ESRC Genomics Network. 
Moreover obesity, also a problem of malnourishment, is increasing in the same areas where hunger lurks.

Fourth, the relationship between humans and their global, regional and local environment is under severe stress. The current system of production and consumption of food has increasingly severe environmental impacts. The production of biofuels, originally a reaction to the depletion and impact of mineral resources is, according to many, a threat to nature, the environment and food production. Extraction of natural resources and appropriation of ecosystem services have in some cases already come to their limits.

Fifth, the latest addition to the environmental constraints concerns the impact of changing climate on agriculture. In a recent study by Federoff et al the impacts are surveyed:

Widespread adoption of more effective and sustainable agronomic practices can help buffer crops against warmer and drier environments, but it will be increasingly difficult to maintain, much less increase, yields of our current major crops as temperatures rise and drylands expand. Climate change will further affect agriculture as the sea level rises, submerging low-lying cropland, and as glaciers melt, causing river systems to experience shorter and more intense seasonal flows, as well as more flooding. ${ }^{6}$

Sixth, unequal economic, social and political power relations on micro-, meso- and macro- levels produce a lot of tensions and enmities. Successful developmental aid bypassing existing power relations is sometimes possible, but mostly not advisable. For instance, developmental aid bypassing national governments in least developed countries often gives rulers the wherewithal to enrich their followers while remaining unaccountable. Much well-intentioned development aid has had adverse effects by reinforcing existing oppressive power relations ${ }^{7}$ or by delivering aid that has adverse effects upon peoples' ability to strengthen their capacities to improve their lives. ${ }^{8}$ Developing new national and international institutional structures is therefore a challenge. The current agricultural and food regime is often part of these problems. It is questionable how far the current agri-food system can tackle them.

\section{Current agricultural systems: a very short summary of the global state of the art}

The dominant 'productionist' system in agriculture consists of high inputs and high outputs on the basis of agro-life sciences. These life sciences focus on increasing yields by concentrating on plants and their predators, by adding pesticides and fertilisers, and by breeding crop varieties that can grow faster under the influence of chemical inputs. The system needs phosphorus, which is becoming scarce, and the price is soaring as a result. The UK newspaper The Times reports: "In the past 14 months, the price of the raw material - phosphate rock - has surged by more than 700 per cent to more than $\$ 367$ (£185) per tonne."9 
The productive reciprocity between chemicals and plant varieties is sought for in elaborate laboratory techniques. Soil characteristics are generally not taken into account by this paradigm of science, and nor are post-harvest events like storage and food processing. This system has been in use since the 1950s, and has had considerable success in increasing yields all over the world, but in particular in the USA and The Netherlands. In their history on rice improvements, Anderson et al confirm that the 'food problem' from the start was reduced to 'yield' and that "low yield was defined as an isolable problem amenable to a scientific solution which could be implemented without prior social and political changes". ${ }^{10}$ Intensification by adding chemicals has considerable side effects, like pollution of surface water, deterioration of soil fertility, decrease of (agro-) biodiversity and the establishing of monocultures. The social system intrinsically connected with this intensive system consists of large-scale organisations that push knowledge from the laboratories to the farmers through extension schemes, seed supply organisations and governmental and privately led financing systems for farmers in need of money for the required largescale investments. Hierarchical, centralised organisations are connected with this large-scale, monocultural system that marginalises the practices of many poor farmers in developing countries and pushes them to slums and unemployment. Although this system can boast considerable advantages (the yields are indeed respectable), is looks as if the price paid is also considerable.

The problems mentioned earlier confront policymakers, scientists and all concerned with the ethical dilemma either to intensify even more strongly the current productionist system or to consider a more plural approach in which several agricultural systems can live next to each other and are encouraged to realise the requirements of the Universal Declaration. Some, indeed, argue for more of the same, ie for including a few more crops than those already in production and for higher intensification inputs (more pesticides, fertilisers and monocultures) to get higher yields; but this strategy runs into the same difficulties. The rich-poor divide, the increasing number of people living in slums (more than 50 per cent of the world's population) and that are hungry and obese, the persistence of malnutrition despite huge aid programmes, and the fact that phosphor will be depleted in 25 years, makes it quite unreasonable to keep to the same path everywhere. However, several alternatives to this 'productionist paradigm' do exist and are currently being explored, whether organic, agri-ecological, low-input high-output or slum (peri-urban) agriculture and Integrated Pest Management (IPM). ${ }^{11}$ It should be said that the alternative science and technology trajectories that support these different systems are not very well funded and are underdeveloped.

What to do with this ethical dilemma of various agricultural (life sciences) paradigms from the standpoint of global justice and the UDHR?

\section{Three different ethical perspectives on global justice}

Different ethical perspectives on global justice, such as utilitarianism and the rightsbased approach, are currently struggling with these severe problems. For instance,

Genomics, Society and Policy, Vol.6, No.2 (2010) ISSN: 1746-5354

(C) ESRC Genomics Network. 
using the utilitarian framework to calculate benefits and losses of the current system of international relations, Peter Singer pleads for uniform standards and rules that can create equality between human beings and between and inside states. ${ }^{12}$ According to his strong cosmopolitan position, there should be international institutions and agencies that can restrain the egotism of national states in defending their interests against poorer states. With respect to common goods, he advocates an egalitarian position that can curb national interests. Many of the problems are global problems and therefore require global solutions (p.199). With respect to agriculture and food, this position seems not to cherish diversity and pluralism of food systems. His position doesn't consider the positive role of diversity at all, and the reciprocal relationship between biodiversity, agricultural diversity, and human biodiversity and local sovereignty of food is not discussed. The dilemma cannot be conceptualised at all in this approach.

Thomas Pogge does pay more attention to the complexities one is confronted with in trying to reduce the growing gap between poor and rich peoples and indeed proposes several measures that could reduce this gap in the field of medicine and medical research. ${ }^{13}$ Starting with the obligation of rich peoples to assist poorer peoples to improve their situation, he emphasises the need for institutional reform of current trade and political relationships. Current international relationships very often stimulate and support the oppressive intra-state relationships which keep people poor. Dictators and corrupt leaders are able to flourish in the current international system, which tends to favour the interests of the rich nations and their citizens. Pogge proposes an institutional reform for the international system and appeals to the rich citizens to cease their support for this system and to start its reform and, finally, to give the rights of access of the poor to cheap medicine full attention. His approach is in accordance with that of others, like Onora O'Neill, who states: "Huge numbers of distant strangers may be benefitted or harmed, even sustained or destroyed, by our action, and especially by our institutionally embodied action, or inaction - as we may be by theirs." 14 However important the role of institutions and that of access to cheap products may be, this should not leave the issue of the quality of life and of the farming practices of poor farmers in the dark. In particular, low prices for food products have the adverse effects that the poor (the over whelming majority of farmers are poor) do not get the entitlements they need for a better livelihood. Low prices for food bring farmers to the brink of collapse. Improving access to food (the kind of strategy Pogge recommends with respect to medicine) is different from, and can even have adverse effects on, improving or enlarging entitlements or farming.

The institutional approach neglects the question of how to secure and improve the agency and practices of poor farmers and does not consider their practices as resources for improving their situation. The poor farmers are at the receiving end of decisions taken by companies and agencies headquartered in first-world countries. ${ }^{15}$ In this approach the dilemma between large scale intensification of agricultural production versus local and global ('glocal') sustainable practices of farmers cannot be conceptualised.

Genomics, Society and Policy, Vol.6, No.2 (2010) ISSN: 1746-5354

(C) ESRC Genomics Network. 
A third ethical perspective is that of Amartya Sen, ${ }^{16}$ who initiated the so-called 'capabilities approach' in attacking the poor-rich divide. He argues that emphasising the rights of the poor is not enough to begin to offer them a comparatively better life, and that the flourishing of individuals in social contexts of respect should be the starting point of global justice practices. Communities don't consist of an aggregation of private interests, and the international and global system should not be reformed top-down without considering the multiple different interests and value orientations of different peoples. Sharing common materials, common values, and common experiences is possible by participation in a society that allows for more variety and diversity than would be possible if individuals were to strive to fulfil their desires and needs on their own. Together with Martha Nussbaum, he is in favour of a kind of moral cosmopolitanism, ${ }^{17}$ but not in favour of the priority of global political institutions (political cosmopolitanism) vis-à-vis national states. They both argue for giving civil society organisations (citizens) a stronger position vis-à-vis governments and markets.

Sen argues that food and nature are not only commodities, or output products, but intrinsically connected with social structures of entitlements and conditions of living. ${ }^{18}$ Commons and other public goods enhance the communal life, and the personal life of the individuals. The essence of these commons is their support by individuals and their distribution to individuals, although the manner of their distribution is often ethically questionable. These public resources must be seen as opportunities for developing and realising capabilities. Moreover, as Nussbaum argues, "(nutritional) needs vary with age, occupation, and gender. Pregnant women need more protein than a non pregnant woman. Women's literacy in many parts of the world will require more resources than men's." 19 Vulnerabilities like disease, poverty, hunger, war, or power relationships are not equally divided. The issue is in how far the poor (in all these aspects) have special rights to be redressed for the unequal distribution of resources and how these resources can be used as opportunities to develop the capabilities of the poor.

Confronted with the at least six substantive, complex and intertwined problems and the dilemma of agricultural production, these global justice perspectives mostly reduce them and come with single solutions, except the position of Sen. One of the failures of most global justice approaches, like those of Singer and Pogge, is their lack of attention to the complexities of agriculture, which must be seen not as an instrument but as a multifunctional common, even a public good, or in the words of Sen, as an "opportunity of living" 20 that in particular in the poorer areas of the world secures food, health, jobs, income, sustainability and self respect in an ethically acceptable way.

Only the approach of Sen pays attention to agriculture and food, but even he doesn't discuss what improvement of the various functions of agriculture in the developing world might mean, although such an improvement is a requirement to reduce

Genomics, Society and Policy, Vol.6, No.2 (2010) ISSN: 1746-5354

(C) ESRC Genomics Network. 
inequalities, improve 'capabilities' and enhance the implementation of justice. Improvement doesn't always imply intensification of agriculture, but at least stabilising and making robust current agricultural practices, so that they can cope with climate and price crises, are sustainable and can guarantee the security and quality of food..$^{21}$ Technological innovations, like GM or biofuel crops, are with respect to these requirements not always promising, to say the least.

One should expect from global justice approaches that they can help in answering questions such as: in how far have agricultural practices incorporated impulses towards innovations improving the quality and quantity of food? What type of innovation impulses and regimes can be encouraged? How can agriculture contribute to lower environmental costs, less contribution to climate change, minimising the use of pesticides, stimulating intercropping and rotation of crops in the battle against pest resistance? How can the incredible diversity of agricultural practices not be seen as a barrier that is to be removed and replaced by one system (applied 'successfully' in large areas of Idaho): the intensive agricultural system? How can we make an asset of this diversity?

More particular questions with respect to conventional and alternative current systems would be, for instance: What types of organic or non-organic fertiliser, and IPM do such systems use and can they use, and how can they learn from each other? Where and how should we use biological control agents (enemies of our enemies), like pheromones traps? And last but not least, how can we enhance the capacities of communities and their members by stimulating the development of their knowledge, experience and political skills?

Because of the lack of attention paid to agriculture and farming, not one of these ethical approaches gives immediately useful advice in answering these questions, which means that all of them have to be accommodated, combined and complemented with another approach.

\section{Alternative: networking agricultural practices}

Sen's approach has one important consideration for the field of agriculture and food: "Political participation and dissent are constitutive parts of development itself." 22 The establishment of democratic process on all levels, from local to global, can improve cooperation by taking into account socio-cultural differences between systems of food production and consumption. By considering the agency of citizens in (agricultural and food) practices, and taking into account the deep-seated differences in power and food preferences, we will give an analysis of Sen's words. At the core of the deliberative democratic approach developed here are the concepts of learning process ${ }^{23}$ with respect to cooperation between different value systems and stakeholders, ${ }^{24}$ the formation of several overlapping publics, ${ }^{25}$ the pluralism of life-, farming and food styles from local to international levels, the interrelationship between debates and decision making process and the necessity of the reflective input of experts. ${ }^{26}$ 
The barriers that prevent global and local coexistence of different agricultural systems bridging the gap between poor and rich can be tackled by taking into account deliberative democratic procedures of deliberations (expressing justice and equality) and substantial concepts (expressing vocabularies of good life). ${ }^{27}$

One aspect of the deliberative democratic approach is the concept of 'ethical room for manoeuvre for farming' (ERM), introduced in $2008^{28}$ and currently being researched in the Department of Applied Philosophy of Wageningen University. The concept urges us not to start with external principles of global justice but with the potential of practices towards a particular end-in-view. Practices of farming, for instance, have to cooperate and exchange ideas and skills; the concept of ERM can be made do-able in multi-level global governance of different agricultural systems by being infused with the concepts of deliberative leadership ${ }^{29}$ and of 'in-between level' or 'bridge' organisations. Leadership is necessary in bridging the differences between several practices, whether horizontally or vertically. I call the required type of leadership 'deliberative leadership' while the deliberative qualities of the intra-practice interaction have to be retained in the inter-practice interaction. The same holds for the concept of 'bridge organisation', which acts as a kind of broker between the practices of one level to that of a 'higher' social level. Many NGOs and farmers' organisations act as a kind of bridge between local farmers and translocal policy and company levels, and negotiate between different groups. They contribute to networking the different practices across the various social levels.

An important aspect of this approach is the emphasis on practices and the agency of constituent members. People, here farmers, are seen as agents who try to live up to the standards of excellence inherent in the practices, and who contribute to improving those standards in response to new challenges. Practices are collectives that combine social, material and cultural aspects, like managements styles, materials to be handled, like soils, plants and animals, and values (standards) to be sought after. The different factors that are covered by the managerial capacities of farmers are soil, water, vegetation and animal management. ${ }^{30}$ Practices are shaped as answers that address the challenges emerging from, for instance, the following dimensions: local versus global; one use versus another of a resource; minimal biodiversity versus long term biodiversity; poor versus wealthy and powerful; flourishing versus lack of freedom; and intensive technologies and extensive use of technologies. The competencies, capacities and strivings of farmers can be stimulated and improved by scientific research that is closely connected with those competencies, capacities and strivings. ${ }^{31}$

\section{Potential of life sciences in tackling problems of global justice}

In view of the six big issues global justice is confronted with, it is clear that current life sciences have to focus on realigning themselves to try to achieve a more just world. ${ }^{32}$ One of the first things to do as a step toward greater global justice is to put into practice a strategy for agenda-setting for these problems. The overall task of agriscience in agenda setting, be it upstream priority setting, or midstream and downstream innovation trajectories, is to consider more pluralism, to be poor-focused

Genomics, Society and Policy, Vol.6, No.2 (2010) ISSN: 1746-5354

(C) ESRC Genomics Network. 
and whole chain-oriented. It would mean that the life sciences put themselves in the service of different agricultural systems, not only of the dominant system. I will concentrate here on agriculture and the potential contributions of the life sciences, mostly plant and soil life sciences. Plant life sciences currently cover technologies such as genetic analysis (sequencing, marker technology used in traditional genetically engineered forms of breeding, genetic engineering) and phenotype analysis (involving physiological, biochemical, or morphological features). All these technologies can be applied to reduce biotic and abiotic stress and to enhance the quantity and quality of harvests. Plant life sciences mostly concentrate on improving the seeds of certain staple crops, and try through either conventional breeding or genetic modification and other biotechnologies (like marker assisted breeding) to increase yields and certain micronutrients in the crop.

However, this pre-harvest-oriented research direction neglects important features of agriculture. First, with respect to growing crops, very often crop management technologies are neglected, like intercropping against pests, root technologies (intercropping of crops with long and short roots, to better use different nutrients from the soil), soil technologies, and push-pull technologies. ${ }^{33}$ Indeed, most of these technologies, which can be improved by life sciences research, belong not to the currently dominant intensive high input agricultural system, but to another, low input, adaptive system.

Second, more criticism can be levelled at the neglect of the ensuing problems in the fields of agriculture and food processing, sustainability, and consumer and farmer acceptance. These approaches are very often developed in defining research agendas and research strategies without seriously taking into account the circumstances that lead to food shortages and malnutrition. The innovation trajectories to produce enhanced and biofortified crops are formulated as 'end of pipe' solutions. ${ }^{34}$ Golden Rice is a typical example, in which post-harvest problems are set aside as 'practical concerns' that can be handled afterwards, as uncritically stated by the Task Force of the ILSI International Food Biotechnology Committee:

Though not directly related to safety, there are matters of practical concern that should be addressed as part of a comprehensive release strategy. While theoretically capable of supplying nutritionally relevant levels of carotene after processing, storage, and cooking needs to be determined before efficacy is demonstrated. Moreover, some have questioned if yellow rice will prove acceptable to people who traditionally eat white polished rice. ${ }^{3}$

When local circumstances are not seriously taken into account and when thought is not given beforehand as to how far research instruments are suitable for enhancing crops in their local contexts, these approaches very often lead to severe failures. These strategies make people dependent on buying enhanced seeds yearly, which they probably cannot do their whole lives, and moreover, very poor people can not afford to buy these things at all. The programmes do not start with the indigenous knowledge 
and practices of farmers but are formulated from a technology push position. How far the enhanced crops will push out poor farmers, and are only affordable to rich farmers, is not considered, and agronomic and environmental issues like water scarcity and land and soil resources are not taken into account. ${ }^{36}$. Alternative strategies (such as those discussed by Wekundah ${ }^{37}$ ) could have more impact (see also Altieri $^{38}$ and Crocker $\left.^{39}\right)$.

Third, with respect to the post-harvest aspects of agriculture, it is very often doubtful how far the enhanced properties of the crops retain their features in storage (for example, certain fungi that act as pests), cooking, preparing and in digesting (bioavailability and digestibility). To consider the whole spectrum of agricultural activities that maintain the current state of hunger and malnutrition is also to consider the way harvesting is carried out, how crops are stored and processed, and how and which long-term management decisions are made by farmers. According to an FAO report about prevention of post-harvest food losses:

Post-harvest losses of food grains in the developing world from mishandling, spoilage and pest infestation are put at 25 per cent; this means that one-quarter of what is produced never reaches the consumer for whom it was grown, and the effort and money required to produce it are lost-forever. Fruit, vegetables and root crops are much less hardy and are mostly quickly perishable, and if care is not taken in their harvesting, handling and transport, they will soon decay and become unfit for human consumption. Estimates of production losses in developing countries are hard to get, but some authorities put losses of sweet potatoes, plantain, tomatoes, bananas and citrus fruit sometimes as high as 50 per cent. Reduction in this wastage, particularly if it can economically be avoided, would be of great significance to growers and consumers alike. ${ }^{40}$

It is interesting to see that these quite important (management) technologies are not, on the whole, addressed in reports about the potential improvement of agriculture. Even the quite broad Royal Society overview of crops technologies does not address post-harvest issues. ${ }^{41}$ Yet farm management strategies can be improved, for example in the way farmers schedule their time in planting, harvesting, obtaining seed, and in how far they get basic information about food and agricultural trends.

Life sciences can make a difference; for example in examining and improving soil root interactions and in analysing storage possibilities (for instance, against fungi) and preparation of foods. ${ }^{42}$ However, one should warn against a top-down approach here. The complexity and variety of soils, climate, management capacities and human cultures always necessitates finding out what the local practices are and what incentives can stimulate farmers to improve the quantity and quality of their crops. For example, the famous search for drought-resistant plants can give rise to the idea that there is only one method to make a plant drought-resistant. This is a mistake, because, as is Pollack has spelled out, a rice variety that can live longer in dry circumstances has difficulty surviving situations of sudden wetness: "After several 
generations, the crops are indeed more resistant to drought. But there is a downside in that they often turn out to have lower yields when there is plenty of rain." single approach is likely to suffice for all types of dry conditions; even such an apparently straightforward decision about how to make a plant drought-resistant has several 'how's and needs therefore to be made dependent on the local practice. The same holds with respect to life sciences technologies that can be used for better storage and processing.

All these examples demonstrate that plant life sciences need to develop as a technology that does research and innovates for different agricultural systems. The current practice, however, is that only the dominant system is supported, with detrimental results, because that maintains the gap between poor and rich and is not sustainable. Nevertheless, the opposing agricultural and food systems and their social, technological and epistemological differences require new democratic arrangements on all levels for support from the side of the life sciences. ${ }^{44}$ The barriers that prevent coexistence of different agricultural systems, whether globally or locally, a coexistence that can bridge the gap between poor and rich, can be tackled by taking into account deliberative democratic procedures. ${ }^{45}$

The current mismatch between the research trajectories of the agricultural life sciences, their assumed high-input, seed-oriented context and the actual agricultural context of food problems in Africa, calls for researchers to redefine their research agendas. The issue is not: shall we develop life sciences to reduce the gap between the rich and the poor; but: which type of life sciences, in connection with other measures, can be developed fruitfully, efficiently and ethically in reducing this gap? The researchers in the developed world should cut across the usual distinction between local and global and pay more attention to the research needs of the poorest peoples and realign the research agenda of multidisciplinary life sciences projects with their needs.

\section{Conclusion}

In this paper on the contribution of life sciences to global justice, we first have sought out what global justice requires from the point of view of generally accepted international declarations and from an ethical point of view. Second, we tackled the question of how far life sciences can contribute to global justice and what directions and what priorities of life sciences research should be selected to help perform this noble task.

Taking seriously the problems I have sketched, the tasks of life sciences as an agriscience would be: to reckon with several agricultural and food systems (agripluralism); and to develop technologies that take into account the practices of the poor to produce, process and consume food. This whole chain-oriented approach, from production (ie. harvesting) to storage, processing to consumption, requires that life scientists do more than just doing research in laboratories but also connect their work with farmers' experimentations. 
${ }^{1}$ Wagningen University, The Netherlands. michiel.korthals@,wur.nl

${ }^{2}$ O. De Schutter. 2009. Seed Policies and the Right to Food: Enhancing Agrobiodiversity and Encouraging Innovation. Report presented to the UN General Assembly (64th session) (UN doc. A/64/170).

${ }^{3} \mathrm{http} / / /$ www.un.org/en/documents/udhr/index.shtml (accessed 19 May 2011).

${ }^{4}$ J.C. Glenn, T.J. Gordon and E. Florescu.. 2009. State of the Future. United Nations University. http://www.millennium-project.org/millennium/sof2009.html (accessed 19 May 2011).

${ }^{5}$ Drugs for Neglected Diseases Working Group. 2001, Fatal Imbalance, p.10, http://www.doctorswithoutborders.org/publications/reports/2001/fatal imbalance short.pdf (accessed 19 May 2011); B. Milanovic. 2005. Worlds Apart: Measuring International and Global Inequality. Princeton: Princeton University Press.

${ }^{6}$ N.V.Federoff et al., Radically Rethinking Agriculture for the 21st Century. Science 12 February 2010: 833-834.

${ }^{7}$ D. Moyo, 2008. Dead Aid. Why Aid Is Not Working and How There Is Another Way for Africa. New York: Farrar, Straus and Giroux; T. Pogge. 2008. World Poverty and Human Rights:Cosmopolitan Responsibilities and Reforms. Cambridge [etc.]: Polity Press.

${ }^{8}$ R. Thurow and S. Kilman, 2009. Enough. New York: PublicAffairs: "A band-aid for the poor is now an industry for the rich." p.xvii.

${ }^{9}$ L. Lewis. Scientists warn of lack of vital phosphorus as biofuels raise demand. The Times, 23 June 2008; N. Gilbert. The Disappearing Nutrient, Nature. October 2009; 461(8): 716-718.

${ }^{10}$ R. Anderson, E. Levy \& B. M. Morrison. 1991. Rice Science and Development Politics: Research Strategies and IRRI's Technologies Confront Asian Diversity, 1950-1980. Oxford: Oxford University Press (p.361, see also p.53).

${ }^{11}$ M.A. Altieri \& P. Koohafkan. 2008. Enduring Farms: Climate Change, Smallholders and Traditional Farming Communities. Environment \& Development Series 6; S.B. Brush. 2004. Farmers' Bounty: Locating Crop Diversity in the Contemporary World. Princeton: Yale University Press; D. Crocker. 2008. Ethics of Global Development. Cambridge: Cambridge University Press.

${ }^{12}$ P. Singer. 2002. One World: The Ethics of Globalisation. New Haven: Yale University Press (p.179).

${ }^{13}$ T. Pogge. 2008. World Poverty and Human Rights. London: Polity.

${ }^{14}$ O. O'Neil. 2000. Bounds of Justice. Cambridge: Cambridge University Press (p.187).

${ }^{15}$ C.Timmermann \& H. v.d. Belt. Global Justice in the Age of Intellectual Property: The right to health and access to medicines. Medizin und Menschenrechte, Volume 4, Vandenhoeck \& Ruprecht, forthcoming.

${ }^{16}$ A. Sen. Food and Freedom. World Development 1989; 17: 769-781; A. Sen. 2010. The Idea of Justice. London: Penguin; see also Crocker, op.cit. note 11.

${ }^{17}$ M. Nussbaum. 2006. Frontiers of Justice. Cambridge: Harvard University Press

${ }^{18}$ Sen, op.cit. note 16 .

${ }^{19}$ Nussbaum, op cit. Note 17.

${ }^{20}$ Sen, op.cit. note 16, p. 235 .

${ }^{21}$ G. Tansey. \& T. Rajotte. 2008. The Future Control of Food. London: Earthscan.

${ }^{22}$ Sen, op.cit.note 16.

${ }^{23}$ J. Habermas. 1996. Between Facts and Norms: Contributions to a Discourse Theory of Law and Democracy, Cambridge: MIT Press.

${ }^{24}$ S. Benhabib (ed.). 1996. Democracy and Difference: Contesting the Boundaries of the Political. Princeton: Princeton University Press.

${ }^{25}$ J. Bohman. 2007. Democracy Across Borders. From Demos to Demoi. Cambridge: MIT Press.

${ }^{26}$ J. Gastil (ed.). 2005. The Deliberative Democracy Handbook. San Francisco: Wiley.

${ }^{27}$ J. Keulartz, M. Schermer \& M. Korthals (eds.). 2002. Pragmatist Ethics for a Technological Culture Dordrecht: Kluwer; J. Keulartz. M. Korthals. M. Schermer \& T. Swierstra. 'Ethics in a Technological Culture. A Programmatic Proposal for a Pragmatist Approach'. Science, Technology and Human Values 2004; 29 (1): 3-30; M. Korthals. 2004. Before Dinner: Philosophy and Ethics of Food. Dordrecht: Springer (p.211). 
${ }^{28}$ M. Korthals, Ethical Room of Manoeuvre, Journal of Agricultural and Environmental Ethics 2008; 21: 249-273.

${ }^{29}$ C.J.A.M. Termeer. 2006. Vital Differences. On Public Leadership and Societal Innovation. Inaugural speech, Wageningen University and Research Centre Social Science Group.

${ }^{30}$ F. Magdoff. Ecological Agriculture: Principles, Practices, and Constraints. Renewable Agriculture and Food Systems 200; 22: 109-117.

${ }^{31}$ Brush, op.cit. note 11 .

${ }^{32}$ N. Clark. J. Mugabe \& J. Smith. 2007. Governing Agricultural Biotechnology in Africa: Building Public Confidence and Capacity for Policy-Making. Nairobi: ACTS.

${ }^{33}$ The Royal Society. 2009, Reaping the Benefits. Science and the sustainable intensification of global agriculture. London: The Royal Society.

${ }^{34}$ IAASTD. 2008. International Assessment of Agricultural Knowledge, Science and Technology for Development. http://www.agassessment.org/ (accessed 19 May 2011).

${ }^{35}$ Task Force of the ILSI International Food Biotechnology Committee. 2008. Chapter 5: Golden Rice 2. Comprehensive Reviews in Food Science and Food Safety, 7: 92-98.

${ }^{36}$ R. Johnson. Sustainable Agriculture: Competing Visions and Policy Avenues. International Journal of Sustainable Development \& World Ecology 2006; 13: 469-480.

${ }^{37}$ J.M. Wekundah. Genomics for the Poor: An Analysis of the Constraints and Possibilities for Social Choices in Genomics for Developing Countries. Tailoring Biotechnologies 2005; 1 (1).

http://www.tailoringbiotechnologies.com/ (accessed 19 May 2011).

${ }^{38}$ Altieri, op.cit. note 11

${ }^{39}$ Crocker, op.cit. note 11 .

${ }^{40}$ FAO. 1989. Prevention of Post-harvest Food Losses: Fruits, Vegetables and Root Crops. A Training Manual. Rome: FAO.

${ }^{41}$ The Royal Society, op.cit. note 33

${ }^{42}$ P. Pingali. 2007. Will the Gene Revolution Reach the Poor? - Lessons from the Green Revolution. Mansholt Lecture, Wageningen: WUR; H. Singhs, Reorientation of Agricultural Research for Addressing Food Security Issues Through Agricultural Biotechnology. Asian Biotechnology and Development Review 2007; 9(3): 83-93; R.K. Varshney, A. Graner \& M.E. Sorrells. Genomics-assisted Breeding for Crop Improvement. Trends in Plant Science 2005; 10(12): 612-630.

${ }^{43}$ A. Pollack. Drought Resistance Is the Goal, but Methods Differ. New York Times, October 232008.

${ }^{44}$ N. Hassanein. Practising Food Democracy: A Pragmatic Politics of Transformation. Rural Studies 2003; 19: 77-86.

${ }^{45}$ Keulartz, op.cit. note 27; Korthals, op.cit. note 27. 